\title{
Reversing the Secularist Drift
}

John COURTney Murray

\section{T}

$\mathrm{HE}$ starting point of these summary reflections may be put in the considered words of one of the greatest of contemporary Catholic thinkers: "Underneath the countless surface currents that are bearing in all directions the thought of our contemporaries, there is, it seems, a deeper current that long ago set in-one might perhaps better call it an enveloping drift: by the action of a considerable portion of its élite of thinkers Western humanity is denying its Christian origins and turning away from God." The drift, as described by $\mathrm{P}$. de Lubac, is toward an atheism that consciously sets out to be "positive, organic, constructive," a dynamic anti-Christianity and anti-theism, bent on destroying in its very terms the problem of God by destroying the traditional concept of man, and setting in its place a positive new ideal-a humanism without God, supported by all the resources of science, and invested with messianic pretensions. This is the new "thing" that has appeared on the human horiżon-a thing much bigger than any of its human creators or servants, that organizes them at the same time that they organize it; for it is in effect a new organization of the world, without God, and therefore against man.

The appearance of this new thing puts to the Catholic intellectual, individually and in his solidarity with his fellow Catholic thinkers, two fundamental problems that are also responsibilities. One is a problem of understanding; the other is a problem of action. The "élite of thinkers" by whose action humanity is being cut adrift from its religious and metaphysical moorings - who are they and what do they teach?

\footnotetext{
${ }^{1}$ H. de Lubac, S.J., Le drame de l'humanisme athée (Paris: Spes, 1945), p. 7.
} 
And the élite of Catholic thinkers-how shall they launch a vigorous counteraction?

The initial responsibility of the Catholic intellectual is, then, that of undertaking a comprehensive analysis of the present intellectual, cultural, and spiritual situation in its totality. If we are to interpret the world, as we must, even to itself, our first duty is to understand it, in detail, with full realism, under abnegation of the easy generalities with which the world is ordinarily denounced. The ringing phrases of the prophets of doom serve their purpose, which is to alarm the Christian conscience that it may flee error and evil. But there is a more comprehensive purpose, which is to enlighten the Christian intelligence that it may overcome error and evil. In this higher doctrinal task the Catholic intellectual is enlisted; therefore he must know with fuller sympathy and speak with greater nicety, conscious always of his primal duty to seek and love and liberate the truth that is at the heart of every error.

In the United States this initial intellectual responsibility takes on a particular urgency at the present moment; for it is a moment of definably special crisis. Take St. Thomas' statement of the essential twofold human endowment, that man "has reason-and hands," ${ }^{2}$ and you will have the terms in which the crisis may be broadly stated: in the United States the traditional cultural emphasis has been on the "hands"; now an emphasis on "reason" begins to be needed. In the past we have been largely content to use our hands (and the practical intelligence that guides the hands and devises tools to be the prolongations, as it were, of the human hands) in the work of building a City, an order of democratic institutions and culture. Now, however, we are being compelled to pause and reflect on the manner of our building and on the foundations on which it rests. The impulse to speculative

${ }^{2} S u m m a$ Theol., I, q. 91, a. 3 ad $2 \mathrm{~m}$. 
reflection has been twofold. Under severe challenge from without, American culture is being forced more explicitly to formulate its own premises and goals, more consciously to experience its own dynamisms. It must justify itself to itself. Again, the realization has struck home to many that in the course of all our furious building we have succeeded in erecting an immense structure that encloses-a vacuum. The intellectual, moral and spiritual vacuities perceptible in many regions of American culture have given rise to the anxious reflection, How shall these hollow emptinesses, within man, within his institutions, be filled?

I am suggesting that an alteration in the American attitude is discernible - a relenting of an old emphasis on the practical, a turn to more speculative rationalization. The phenomenon needs verification in detail. But accepting it as the fact, and putting it in the context of the world-wide "drift" of thought and feeling defined above, one must ask a series of grave questions. Is this drift catching also the United States in its current? And how strongly? What is the stage of growth among us of a purposively secularist, even atheist, humanism? How far is American secularism a negation and how far is it a positive creed? Is it any longer simply a pragmatic attitude, born of a careless or a critical agnosticism, or is it becoming a consciously formed philosophy? To what extent is the American college an instrument of its construction and propagation? And what areas of life are coming under its control? The contemporary critical reflection on the meaning and foundations of democracy-how much is it under the intellectual guidance of traditional Christian principle, how much under the untrustworthy sentimental guidance of a vague humanitarian mysticism, how much under the more sinister guidance of forces that owe nothing to Christian inspiration? In sum, at a moment of crisis in our national growth, when American thought and manners of institutional life are being organized with new reflectiveness, is this organization taking place without $u s$-without God or even against Him? 
These are important questions, to which we badly need answers-exact answers that can be reached only by careful study. Otherwise our intellectual apostolate will lack focus, will risk preoccupation with the peripheral, will waste itself in manning breaches not under attack, what time the enemy streams through other, unguarded gates. We need to know, for instance, the exact strength of the most prominent candidate for filling the spiritual vacuum at the interior of our culture; I mean the myth of "democracy as a religion," a secularist faith, created without reference to God or any transcendent law, claiming to be the successor to sectarian Christianity, a more peaceful creed and a more operative one, with a higher, more unifying mission, and more totally salvific resources. Again, we need to know more than we do about the impact of science on our culture, about the climate of opinion it has created, about the concept of "reality," the imaginative picture of the universe it has fostered, about the mental habits it has induced, and especially about the redemptive significance it attributes to itself as a method of controlling human life and transforming the conditions of its living.

I am myself much concerned about the way in which Science (I do not mean just the scientific disciplines but the total pervading "thing" that has about acquired for itself a capital letter) is tending to undermine the bases of that high intellectualism which, together with the dogmatic principle, is of the essence of Catholicism. The tendency of the "thing" is to narrow the field of reality and the scope of intelligence, to accord primacy to the material and make the spiritual only the symbol of the material, to confine all thinking to the categories of the temporal, the quantitative, the relative, to assert sheer process and deny all order, to discard finality in favor of efficiency and the "idea" in favor of the "fact," to regard anthropology and psychology as the supreme sciences of man, enthroned in place of philosophy and theology. There is in all this a certain defacement of the image of God in man- 
a disintegration of rationality, a movement of man toward absorption in matter and its processes. Human nature itself is being devaluated, in the devaluation of that high faculty whereby man is radically capable of God and of grace. And the Church, which loves intelligence itself hardly less than its sacrifice in faith, is deeply concerned.

II

The contemporary intellectual milieu therefore puts to the Catholic intelligence a problem of understanding. "The first apostolate at the present crossroads is in the realm of thought," said Cardinal Suhard ${ }^{3}$ and perhaps its first phase consists in the mastering of today's myriad currents of thought that, insofar as they are part of an immense "drift," are carrying Western man away from his origins and from God. However, there is then the further more decisive phase - that of reversing the drift, of altering the secularist climate. This is an enormous subject, on which I offer only some suggestions.

The initial one is that the Catholic intellectual and the Catholic college and university must resolutely refuse to succumb to what is perhaps the most insidious temptation-the "temptation of Thabor." There is perhaps some self-examination needed here. Again I merely suggest the questions. Is the Catholic scholar a self-inclosed spiritual monad in a secularist world? And is the Catholic institution of learning simply a citadel, a fortress of defense, or an asylum of escape? Does it exist on the periphery or at the center of the present cultural crisis? $\mathrm{Has}$ it an orientation rather sectarian than Catholic in the adequate sense? It is the focus of purely centripetal movements, all its currents incoming, none outgoing?

Whatever be the actual case (and it bears, I say, examination), one thing must be considered indisputable - that the Catholic college and university today ought to be the point of departure for a missionary effort out into the thickening

${ }^{3}$ Essor ou déclin de l'Église (Paris: Les Editions du Vitrail, 1947), p. 42. 
secularist intellectual and spiritual milieu. Their function in the Church and in regard of the children of the Church requires to be completed by discharge of a function in the world and in regard of those who stand without. It is not enough to stand firm against the drift; for after one has stood firm, the drift itself still continues to sweep other minds and souls off into the shallows and on to the rocks.

What is needed in this respect is perhaps not so much conviction that this intellectual function ad extra is a responsibility, as confidence that the responsibility may indeed be effectively discharged. The imposing question that gives pause is, Can the drift be reversed, the climate altered? But the rapid answer, cutting short the pause, must be a confident Yes. A Yes spoken not with blind confidence, but with a coldly intelligent, fervently faithful confidence; for we have available all the doctrine of Pius XI, and its elaborations by other thinkers, in regard of the techniques of social change; it remains only to apply them with proper adaptations to the problems of an intellectual milieu. What an élite of thinkers have done-consider, for instance, that a bare handful of men accomplished the intellectual revolution of the eighteenth century-another élite can do.

Nor is it difficult to know what should be the fulcrum of their effort. Every milieu has its key institutions that set its tone and determine the pressures that it will exert. And the crucial institution in the case is the university graduate school. An Episcopalian minister of long educational experience, Dr. Bernard Iddings Bell, writing recently of the problem of religion in education, put his finger on the matter when he noted the intellectual dependence of the college faculty as well as student on the graduate and professional schools, in which attitudes, opinions, the whole "set" of thought are fixed: "In short, the core of any problem having to do with American higher education, including the problem of religion, will be found not in the colleges but in the universities and, within the universities themselves, not in their 
undergraduate sections but among the research scholars in the graduate and professional schools." Nothing could be more true, more fundamental to the problem of the intellectual apostolate, and I may add, more hopeful; for there are probably no more than half a dozen centers of learning in the United States that are essentially determinant of a whole intellectual drift.

Here would be the field for which "missionaries" would need to be trained. The term is doubtless bad, as suggesting "evangelization" in some narrow sense. I am thinking of "presence" in these centers on the only title which admits to presence - ability, learning, scholarly achievement. The active finality of such "presence" and the manner of achieving it would be difficult to define; there is need of study and experiment here, for in the field of the intellectual apostolate all is pioneering. At all events, the basic thing would be alliance with the intrinsic purpose of the university-teaching, research, writing, direction of studies, conference; and then, in and through this intellectual work, as itself an apostolic medium, the mediation of Christian truth and the Christian spirit to the institution itself, in ways that only they could come upon who were actually about the work of mediation. No one could say with programmatic apriorism what the opportunities would be; but one can say this: granted that at the moment almost the whole weight of higher learning in the United States is being thrown against all that we mean by Catholic intellectualism and Catholic faith, it would be quite possible to shift this weight by conscious, directed, collective effort. Obviously, an effective intellectual apostolate does not just happen; there is organization needed. On the other hand, I do not think that this is the kind of apostolate that can be or should be highly organized; always it will be intensely personal. However, there are perhaps three things that can be done, by way of mobilization-to call it that-of resources. We have in fact three great resources.

4"Studying Religion in Universities," Christian Century, Sept. 22, 1948, p. 975. 
The first is both a quantity and a quality of intelligence. It exists on the campuses of our Catholic colleges. But there is too little conscious effort made to locate it, stimulate it, and do what one can to turn it to the uses of the intellectual apostolate. I say, "do what one can"; for there are limitations. The intellectual apostle must needs be first and last a scholar. And scholarship results from an autonomous dynamism. It has its own separate roots in a strange special soil. It is not the automatic result of piety, for instance, as if one would love learning simply because one loves God. Basically, one loves learning simply because one loves learning, and for this high love is willing to submit to the rigorous disciplines of the scholarly life. It is not possible therefore to "promote" scholarship any more than it is possible to improvise it.

However, it is possible to create the conditions under which this autonomous dynamism will assert itself. Every savant is the product of a milieu, part of a tradition, in which ideals of scholarship prevail and are illustrated in living models. He first came to know his own powers in the midst of those who were exercising theirs; his aspirations began to stir under the lift of a communal aspiration surrounding him. As Thomas had his Albert and Bellarmine his Lessius, so every master, while a pupil, had a master from whom he caught the ideal of being master. Does not this point to a responsibility that rests in solidum on the Catholic college facultythe responsibility of creating and sustaining an atmosphere favorable to the cultivation of high intelligence. In the routine training of the ordinary "good Catholic," we perhaps do well enough; but I sometimes think we fail those who are most gifted. Moreover, in addition to the task of creating the conditions wherein a love of learning may grow, if its roots are there, there is the further task of recognizing the talent that appears, and urging upon it, with all discretion indeed but with a measure of challenge, the vocation to scholarship. The secular universities (one thinks of Princeton, for instance) have set us a pattern here that we would have done well to 
devise ourselves. (There arises here, as always, a financial problem - that of paying the way through graduate school of many able students who have the equipment and the inclination for scholarly work but who without assistance could not go on to it.)

Deliberate recruiting of talent is a first step. There is the further one of forming for this peculiarly exigent apostolate those who embrace it. Here of course we have as our resources the whole doctrine, the whole sacramental reality of the Church and her indwelling Spirit. The problem is to use these infinite resources; more particularly it is the problem of conceiving and administering the special type of spiritual formation that is needed. This raises of course the whole question of a "lay spirituality." Something has been done on the subject for the "man of action"; not much has been done for the "man of thought." This is a subject in itself; I would only say that the problem of the spiritual formation of the young graduate student ( $\mathrm{I}$ am chiefly supposing that he is in a secular graduate school) and his continuing formation as professor or research scholar is one to which the priest and the layman must address themselves cooperatively. Admittedly, the problems of the spiritual life are always generically the same-prayer, active charity, self-discipline, liturgical and sacramental practice, the development of the virtues, growth in self-knowledge, attention to particular calls of the Holy Spirit, etc. But in a lay context, and in an intellectual context, they rise in particular forms and need a solution that is properly nuancée. This solution can be given its nice form only by one who stands within the context, aided by the priest, who always in a sense stands without. The religious and apostolic formation of the Christian intellectual is a task of great delicacy; perhaps a Bernard could write a new De Consideratione so pointed as to be a manual of guidance in its accomplishment, but I suspect, as I say, that any manual on the subject would have to be done with the assistance of a lay hand. 
The third great resource for an effective intellectual apostolate is one that the Catholic Commission on Intellectual and Cultural Affairs by its sheer existence, as it were, dramatizes. I mean the intellectual and spiritual solidarity that is so much our Catholic birthright (and so little, I at times think, our Catholic achievement). How needful this solidarity-as realized and made fruitful of action - has become must be evident to anyone who considers the situation that confronts us. Today no isolated solutions are good enough, because there are no isolated problems. Everything has become part of everything else, and-non omnia possumus omnes. Therefore collective thought has become the order of the day. It has always been a Catholic thing; is not the mighty edifice of Scholasticism a testimony to its efficacy? Our concept of the studium has always been that of a corporation of scholars in living contact with one another, mind clashing with mind, and out of the conflict, which is also a collaboration, emerging a corpus doctrinae, that becomes the common property of the corporation. Today a new vitalization of this ancient Catholic principle is imperative. I should take quite seriously Cardinal Suhard's statement: "The hour is come in which the greatest service that could be rendered to the Church and her children would be to put together the 'Christian Summa' of the world that is now taking shape." It will not, he adds, be the work of a day, or of one man. It could not ever be enclosed within the covers of one book. It is a synthesis on which a multitude of minds, from all the intellectual disciplines, must labor-philosopher and scientist, artist and theologian, historian and jurist, journalist and littérateur, psychologist and pastor, moralist and statesman. In its elaboration Newman's "principle of personality" will still be valid; for thinking must always be done by individual men. But the complementary principle of solidarity will likewise be valid; for the materials of thought have today become too vast for one man's mastery. (To take one example, who could assimilate enough history, political

\footnotetext{
${ }^{5}$ Loc, cit.
} 
philosophy and political science and sociology, canon law and theology to effect the needed synthesis of Catholic thought, in its historical and doctrinal dimensions, on the problem indicated under the rubric, "Church and State"?)

For this needed collective and cooperative work we have the resources. There is our unity of faith, our shared philosophy, our singleness of apostolic aim. There is too our Christian friendship, that makes possible fierce argument and much disagreement, under preservation of the bonds of union that will lead argument and disagreement to peaceful issue. As a symbol of this friendship, newly cemented, and therefore a promise of fruitful collaboration in and toward the intellectual apostolate, the CCICA stands significantly on the scene.

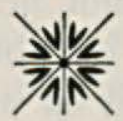

